\title{
Isolation and Utilization of Natural Dye (Lac Dye and Arjun Dye)
}

\author{
*Seatara Khatun, G. R. M Astaq Mohal Khan, M.L.Rahman, Kobad Hossain, \\ Md. Jahidul Islam and Ayesha Akhtar. \\ BCSIR Laboratiries,Binodpur Bazar, Rajshahi- 6206.
}

\begin{abstract}
Lac dye was isolated from washings of stick lac and Arjun dye was extracted from Arjun fruits and its mixed dyeing properties on silk and cotton fibre were studied on silk it produced deep coffee colour and cotton deep brown colour shades using alum as mordant shades varied is colour when other mordents like copper sulphate chromium, sulphate and stannus chloride were used.
\end{abstract}

Key Words: Seed lac, Arjun fruits, Sodium carbonate, Alum, Copper sulphate, stannus chloride, Chromium, sulphate, Acetic acid \& Formic acid.

\section{Introduction:}

Lac is a resinous substance secreted by some insect, kerria Lacca on some selected host plants . Encrustation of lac on the twigs of host plants when scrapped, crushed and washed with water gives pinkish solution due to the presents of colouring matter of the bodies of lac insects. This dye is acidic in nature and is present in the lac most probably as its sodium and potassium salts which are completely soluble in water. The isolation of lac dye has been reported by various worker ${ }^{1,3}$. Schmidt, Dimroth and Helen Mitrea ${ }^{4,6}$. employed methods for isolation at lac dye which are elaborate and time consuming. The aquous extract start regenerating it even left over night. So a rapid method is required to be employed for its isolation. Kamath and Potnish ${ }^{7}$ worked out an easy method for isolation .

Natural dyes are the gift of nature. They are obtained from the roots, barks, leaves fruits or wood of the plants ${ }^{8}$. In ancient time all natural dyes were obtained from natural sources ${ }^{9}$. Natural dye exhibit better biodegradability, compatibility with the environment and possess lower toxicity and non allergic reaction on human body ${ }^{10,11}$. Some natural dye give long life shade on cotton fibre ${ }^{12}$. A dye is a material that absorbed strongly in the visible region or physical attraction between the dye and the dyes sabstance ${ }^{13}$. For a Substance act as a dye must be resistance to water, alkali and acid ${ }^{14}$.

( Indigo) a blue dye, (Turmeric ) a yellow dye, ( Catechu ) a brown dye, (Latkan) an orange dye all are obtained from the different parts of the plants. They are chemically identical to natural dyes ${ }^{15}$ ie, a chacholate Arjun dye can be extracted from the fruits of Arjun plants. The fruits contain 6-7\% chacholate dye.

\section{Materials and Methods:}

(a) Isolation of Lac dye : For isolation of lac dye row lac samples were collected from Baisakhi and katki crops. Ten (10) batches of measured quantity of row lac ( Stick lac) were taken, crushed and washed with $2 \%$ sodium carbonate solution. Each batch of $1000 \mathrm{gms}$, was washed 5 times and the washing containing water soluble dye was collected. Concentrated by evaporation and acidified with $1 \mathrm{~N}$ hydrochloric acid when a crimson coloured dye precipitated. It was filtered and the precipitated on the cloth filter washed with water and allowed to dry at room temprature. The dried lac dye were collected and ( mixed lac dye with Arjun dye ) directly utilized for silk and cotton fibre.

(b) Extraction of Arjun dye : Arjune fruits ( Terminalla) were collected from BCSIR campus, Rajshahi, for the extraction of dye. The collected fruits were washed with water to remove the adhering materials. The fruits were dried in normal temperature. The fruits were then smashed in a wooden morter. The smashed were then boiled with water for 8 hours in a stainless steel beaker. Fruits and water ratio was 1:1 The extraction was repeated second and third times with fresh water in the same condition. The exstract were filtared through markin cloth to remove the pith and were concentrated paste like mass was used as Arjun dye.The direct lac dye and Arjun (mixed lac dye with Arjun dye) dye were directly utilized for silk and cotton fibre.

Silk fibre was collected from Bangladesh Sericulture Research and Training Institute Rajshahi and the cotton fibre was collected from local market.

\section{Dyeing of silk and Cotton fibres:}

Degumming of silk and cotton fibre: For degumming, a soap solution of strength $3.5 \mathrm{~g} /$ litre was prepared by adjusting the $\mathrm{pH}$ 10.5. Silk is a natural animal protein fibre. As silk exhibits both acidic and basic properties it can be dyed with almost all types of dyes direct, acid, basic, reactive, vegetables dyes etc. Now the silk fibre 
was dipped in to the soap solution and then heated at $1000 \mathrm{c}$ for 1 hour. After degumming the fibre was washed 2-3 times with distilled water. The same degumming procedure was followed in case of cotton fibre.

Mordanting of silk with alum : Dyeing is the process by which the dye is appplied in the substance being died 16. Mordanting bath was prepared with $0.5 \%$ alum in a $250 \mathrm{ml}$ beaker $1 \mathrm{gm}$ of stock sample of silk was dipped into the mordanting bath in cold and heated to boiling for 30 minutes with occasional stirring . The bath was allowed to cool. The mordanted silk was taken out, squeezed and dried at room temperature. In the similar way, silk sample was mordented with copper sulphate, chromium sulphate and stannus chloride.

A dye bath ( $250 \mathrm{ml}$ beaker ) was prepared by dissolving $2.5 \mathrm{gms}$ of crude Lac dye and 2.5 gms Arjun dye in $1 \mathrm{ml}$ formic acid and diluted by adding distilled water to make its volume $100 \mathrm{ml}$. Then the solution was heated for 30 minutes with occasional stirring . The bath was allowed to cool. Then it was filtred. Now the mordanted silk sample $(1 \mathrm{gm})$ was dipped into the filtrate and again heated to boiling for 30 minutes, $1 \mathrm{gm}$ of sodium choloride was added and heating continued for further 10 minutes. The dyeing bath was allowed to stand overnight. It was washed well with water and soap and rinsed well with $1 \%$ acetic acid solution and dried at room temperature. The shade obtained was coffee chocolate colour. In the similer way dyeing of mordanted copper sulphate, chormium sulphate, and stannus chloride- silk were completed. The shades produced on copper sulphate mordunted- silk was deep yellowish brown, stannus chloride mordanted- silk was yellowish cream, and chromium sulphate mordanted silk was deep grey in colour.The same dyeing procedure was followed in case of cotton fibre.

Dyeing of unmordanted silk and cotton fibre: $2.5 \mathrm{gms}$ lac dye and $2.5 \mathrm{gms}$ Arjun dye was taken in a $250 \mathrm{ml}$ beaker containing $100 \mathrm{ml}$ of distilled water, $1 \mathrm{ml}$ of formic acid was added and stirred well and heated to boiling with occasional stirring with glass rod for 30 minutes The solution was filtered. To the filtered $1 \mathrm{gm}$ unmordanted silk was dipped and heated for 30 minutes, $1 \mathrm{gm}$ sodium chloride was added and heated for further 10 minutes. The dyeing bath was allowed stand overnight. The dyed sample was then washed well with water and soap, squeezed and then allowed to dry. The shades obtained were cream colour. The dyeing of cotton both mordanted and unmordanted were carried out as described above. The shades produced on samples of silk and cotton using different mordants and unmordant were shown in table 1.

\section{Fastness test:}

Light fastness: The dyes samples of silk and cotton fibre were exposed to sunlight in air for 100 hours and the change in shades were measured with the help of Grey scale. The results were shown in Table- 2.

Washing Fastness: The dyes samples of silk and cotton fibre were washed with soap solution separately for several times. The washing fastness were measured with the help of Gray scale which was shown in Table -2 .

\section{Results and Discussions :}

The percentage of crude lac dye was isolated 7.2, calculated on the weight of raw lac and the percentage of Arjun dye was 6-7, calculated on the weight of Arjun fruits. There dyes were directly used for studying properties on silk and cotton.

Comparing of silk and cotton fibre, on silk dyeing with blended two natural dyes, it produces heavy shades and on cotton, the shades will be light in colour with the same concentration, dyeing time and dyeing temperature. This is due to reason in behind that silk is a protein fibres, its absorption power is high, because it is acidic in nature. On the other hand, cotton is a cellulosic material, its absorption power is very poor than that of silk, because it is basic in character and the fibrous materials of cotton is closely attached. Mordanting may be carried out on fibres because it acts as a key or bridge between the dye and the fibre. So, on mordanting of silk, its fibre will be loosely bound and the dye can uptake easily but on cotton, its fibre do not easily loosely bound and the dye cannot uptake easily.

The shades produced on fibres and fabrics of silk and cotton are shown in Table. It was observed that shades produced alum mordant silk and cotton were coffee and deep brown colour, on copper sulphate mordanted silk and cotton were deep yellowish brown and light yellowish brown, on stannous chloride mordanted silk and cotton were yellowish cream colour and light brown colour. On chromium, sulphate mordanted silk and cotton were deep grey colour and grey colour. 
Table-1: Dyeing effects of silk and cotton fibre with two natural dyes blended and using different mordants and unmordant.

\begin{tabular}{|l|l|l|l|}
\hline Natural dye staff & $\begin{array}{l}\text { Name of the sample } \\
\text { dye. }\end{array}$ & Name of the mordant use & Shades produced \\
\hline \multirow{3}{*}{ Lac and Arjun dye } & Silk & $\begin{array}{l}\text { Alum } \\
\text { copper sulphate } \\
\text { Stannus Chloride } \\
\text { Chromium sulphate } \\
\text { Without mordant }\end{array}$ & $\begin{array}{l}\text { Coffee colour } \\
\text { DeepYellowish brown } \\
\text { Yellowish cream colour } \\
\text { Deep Grey colour } \\
\text { Cream colour }\end{array}$ \\
\hline & \multirow{3}{*}{ Cotton } & $\begin{array}{l}\text { Alum } \\
\text { Copper Sulphate } \\
\text { Stannous chloride } \\
\text { Chromium Sulphate } \\
\text { Without mordant }\end{array}$ & $\begin{array}{l}\text { Deep brown colour } \\
\text { LightYellowish brown } \\
\text { Light Brown colour Grey } \\
\text { colour } \\
\text { Deep cream colour. }\end{array}$ \\
\hline
\end{tabular}

Table 2: Light and washing fastness of two natural (Lac and Aejun dyes) dyes blended on silk and cotton fibres.

\begin{tabular}{|l|l|l|l|}
\hline Name of sample & Mordant Used & Light fastness test grade & Wash fastness test grade \\
\hline Silk & Alum & 4 & 4 \\
& Copper sulphate & 4 & 4 \\
& Stannus chloride & 4 & 4 \\
& Chromium Sulphate & 4 & 4 \\
\hline Cotton & Alum & $3-2$ & $4-3$ \\
& Copper sulphate & 4 & $4-3$ \\
& Stannus Chloride & $3-2$ & $3-2$ \\
& Chromium sulphate & $4-3$ & $4-3$ \\
\hline
\end{tabular}

\section{Conclusions:}

A simple inexpensive method for extraction of two natural dyes and blended with two natural dyes. The dyeing characteristics of silk and cotton fibres was observed by the treatment of the blended dyes. For heavier shades was observed on silk than on cotton by the mordant and at the same reaction conditions. The shades were fast to sunlight and wash.

\section{Acknowledgement:}

The authors wish to acknowledge Dr.Md. Zahurul Haque, Director-in-Charge, BCSIR Laboratories, Rajshahi for his keen interest in the work.

\section{Reference}

[1] Pearson \& John, Phil,Trans, 1794,383

[2] John,Chem,Schriften,Berlin, $1,1806: 5,1816,20$.

[3] G. Hatchet, Phil. Trans.1804,Jour, Nat Phil,1805:Wholers Handb.d. Chem.iii 1848,739.

[4] R. E.Schmidt. Ber, 20,1887,1285.

[5] O. Dimroth, \& S. Goldschmidt. Ann,399,1913,62

[6] H. Mitrea, Diss, Bern, 1934.

[7] N.R.Kamath and S.P. Potnis, lndia, 1953,3,No.1.107.

[8] A.F. Hill. 1951, Economic Botany, $2^{\text {nd }}$ edition, 225, 255.

[9] E.R. Trotman,1975, Dyeing and Chemical Technology and Textile Fibres, 5th edition, 2,618

[10] M.M. Alam, M.L. Rahman and M.Z. Haque, 2007, Extration of Hena leaf and its dyeing effect on textile fibre. Bangldesh J.Sci.Ind. Res 42 (2) 217-222.

[11] V. Kumer, and B.V Bharti,1998, The Indian Textile Journal 18-20.

[12] F.A Margaret and ,A.F Urry, 1945,Rayon Textile, 26, 603.

[13] L.O Smith and S.T Cristoll, 1966, Organic Chemistry, P- 652.

[14] I.L. Finar, 1959. Organic Chemistry $3^{\text {rd }}$ edition, 1, 741.

[15] R.T. Adroska, 1971, Natural Dyes and Home dyeing.

[16] C.R. Noller, 1966, Chemistry of Organic Compounds, P-74. 